\title{
Contos selecionados de Evguêni Kharitónov
}

\author{
Yuri Martins de Oliveira*
}

\begin{abstract}
Resumo: Tradução comentada dos contos "Um morador escreveu um requerimento" e "Traição-80", de Evguêni Kharitónov, inéditos em português até a presente data.
\end{abstract}

Palavras-chave: Kharitónov; prosa soviética; literatura russa

\section{Sobre Evguêni Kharitónov e os contos "Um morador escreveu um requerimento" e "Traição-80"}

Evguêni Vladímirovitch Kharitónov nasceu em 1941, em Novossibirsk, uma das maiores cidades da Sibéria. Aos 17 anos, parte para Moscou para ingressar no Instituto Guerássimov de Cinematografia (VGIK, na sigla em russo), no qual se forma ator. Depois de atuar em pequenos papéis no cinema, Kharitónov retorna ao Instituto e defende a dissertação de mestrado A pantomima na formação do ator de cinema (Пантомима в обучении киноактёра) e, tendo sido aprovado, torna-se professor do VGIK. Nos 1970, além das aulas que ministra no Instituto, Kharitónov dirige peças de teatro e abre seu próprio estúdio de artes cênicas, dedicando-se, paralelamente, à literatura. Com o conto "Forno" (“Ауховка"), de 1969, о escritor começa a delinear o estilo característico, e também passa a tratar do tema que se tornará central em sua obra: a homossexualidade masculina. Embora apareça em muitos de seus escritos e versos, esse tema não se torna o único para o escritor, que escreve sobre questões políticas e culturais, como vemos nos contos "Um morador escreveu um requerimento" e "Traição-80 - Antiutopia". O primeiro

\footnotetext{
* Yuri Martins de Oliveira é aluno de mestrado no Programa de Pós-Graduação em Literatura e Cultura Russa, na Faculdade de Filosofia, Letras e Ciências Humanas.
} 
conto, uma narrativa satírica a respeito da burocracia soviética, faz parte da coletânea que o próprio Kharitónov organizou, em 1981, pouco antes de sofrer um ataque cardíaco fatal, sob o título de Em prisão domiciliar (Под домашним арестом), que só viria ser publicada nos anos 1990; já o segundo, uma ácida previsão sobre o fim da União Soviética e o futuro da Rússia, estava entre os papéis do escritor encontrados por amigos depois de sua morte. Atualmente, Kharitónov é um escritor pouco conhecido entre russos e estrangeiros, embora tenha feito algum sucesso nos anos $1990 \mathrm{com}$ as traduções para o inglês de seus contos e versos a respeito da homossexualidade. As traduções aqui apresentadas são as primeiras para língua portuguesa.

\section{Um morador escreveu um requerimento (Evguêni Kharitónov)}

Um morador escreveu um requerimento ao $\mathrm{JEK}^{1}$, pois o assoalho da cozinha tinha afundado, e o linóleo, fendido, precisava trocar. Ele, a princípio, foi falar com os mestres de obra, estes cobravam vinte e cinco rublos por trabalho. Mas acontece que o JEK faz de graça. A secretária disse - escreva um requerimento ao diretor, primeiro precisa que a encarregada-técnica venha ver, depois é que vão começar; Entregue este requerimento à encarregada-técnica, só que quem dará a autorização é o diretor. A encarregada-técnica veio depois de dois dias, disse que era preciso trocar todo o assoalho da cozinha; se só tapar os buracos, fica malfeito, a base antiga vai começar a ruir em volta (a base era feita não de tábuas, mas de serragem prensada); só que nós não temos linóleo. Depois de mais uns dois-três dias, por ordem dela, veio o mestre de obras, aquele que pedira vinte e cinco rublos pelo trabalho, deu uma olhada, disse não podemos fazer, não temos linóleo. O morador diz pois o linóleo está aqui, olhe, e já faz tempo, eu mesmo comprei². - Ah, então esvazie a cozinha, volto já com meu ajudante. O morador tirou as coisas pesadas. O mestre liga não precisa tirar nada, não iremos, não temos as ripas. O morador liga para a mulher-encarregada - como é que eles não vêm? disseram para esvaziar a cozinha, e agora não têm ripas? Ela titubeou ao telefone - espere um instante... hum... é, não temos as ripas. - E quando é que vão ter? - Daqui uns dias vão trazer, nós ligamos pro senhor; mas faremos até o final da semana. Passam-se alguns dias,

1 Abreviação de Жилищно-Эксплуатационная Контора, isto é, Escritório de Moradia e Manutenção, órgão responsável pela administração regional das moradias nas cidades soviéticas. Criado em 1959, permaneceu em atividade até 2005. (N.T.)

2 A pontuação no original está fora dos padrões russos e não é possível ter certeza de quem fala, se narrador ou personagem. A tradução, assim, reproduz o estilo do original. 
ele mesmo liga - quando vão ter as ripas? Ela diz o senhor ligue de tempos em tempos pra nós. Então ele liga e dizem que vai chegar dali uns dois dias; aí ele liga dali dois dias e dizem que não se sabe quando vai chegar. As ripas, dizem, estão no depósito, mas não tem carro pra trazer. Pois então finalmente ele foi dar queixa da encarregada-técnica, e dizem - acabaram de trazer as ripas, amanhã mesmo começamos. No dia seguinte, aquele mestre de obras vem, diz esvazie a cozinha, já vamos começar a fazer, e mede para ele o linóleo novo, como se fosse cortá-lo. Passa uma hora, nada do mestre. O morador liga, chamam o mestre ao telefone: mas nós vamos começar amanhã, ou então vamos ter de desligar o seu gás, e aí o senhor vai ficar dois dias sem gás. - Mas que diferença faz vocês desligarem o gás hoje e começar só amanhã? dá na mesma; vocês disseram que vinham já, eu estou esperando, esvaziei a cozinha. - Está bem, vamos agora então. Passa uma hora e mais um pouco, o morador se veste e vai à oficina, na rua. $\mathrm{O}$ tal do mestre não está lá, está o ajudante, embriagado. $\mathrm{O}$ ajudante diz volte amanhã. O morador diz mas o mestre acabou de me dizer pelo telefone que já estava chegando; onde ele está? - Ele saiu pra atender um chamado; saiu pra almoçar; ele me disse que ligou pro senhor, mas não tinha ninguém em casa. - Pois eu mesmo falei com ele, medimos juntos o linóleo, ele disse que vinha já, e com as ripas, três horas e nada, aonde ele foi atender esse chamado, em qual casa? eu vou lá encontrá-lo. O ajudante diz - anote, e estende um contraplacado. - Pode falar, fale, eu vou lembrar. Mas o ajudante tinha estendido o contraplacado para que o morador escrevesse ali o seu endereço. - Pra que o meu endereço, o mestre já esteve em casa. - Tá, como quiser. - Você me diga aonde ele foi atender esse chamado, em qual casa, eu vou lá encontrá-lo. O ajudante então deu o tal endereço, trocando os números com os do endereço do morador. O morador foi até a encarregada-técnica dar queixa do mestre de obras. Ela voltou com ele até a oficina, começou a xingar o ajudante, o mestre ainda não tinha chegado, e o outro dizia - o mestre foi de manhã ao apartamento daquele morador que afundou o chão da cozinha, disse que ele não estava em casa, que iríamos amanhã. O morador nem retrucou, viu que seria inútil. A encarregada-técnica ordenou ao ajudante que começasse o trabalho, serrasse as ripas em pedaços do tamanho da cozinha, de quebra ainda expulsou da oficina as pessoas que, como ela acertadamente suspeitara, tinham vindo beber com o ajudante, e foi embora. O ajudante diz - mas como é que eu vou cortar, não sei o tamanho da sua cozinha. Mas todas as cozinhas eram idênticas no bairro todo. O morador diz - está bem, venha comigo fazer a medição. Eis que chegam, ajudante e morador, em casa, o ajudante faz a medição daquele jeito, a régua a torto e a direto, e ele dizendo - tanto faz, antes de três dias não podemos começar, o linóleo tem de ficar descansando três dias antes de fazer o 
revestimento. - Pois é, mas já faz trinta e três dias que ele está descansando no meu quarto! E aí o ajudante diz - Ah, mas se o senhor tem o seu próprio linóleo é outra história, dá pra começar amanhã; então pra quê que eu medi a cozinha pra ver de que tamanho cortar as ripas, se todas as cozinhas são idênticas no bairro todo?; já que o senhor tem o linóleo, e já ficou descansando, então amanhã dá pra começar. - Como assim amanhã, o mestre veio e disse que começava hoje; comece hoje; se não conseguir terminar, amanhã você continua; vá pelo menos serrar as ripas do tamanho certo e trazer pra cá. O ajudante disse tanto faz, sem o mestre não posso. - Não pode o quê? Não pode serrar? - Serrar eu posso, mas como vou trazer? os sarrafos são grandes, não tenho força de carregar. - Está bem, você vai e corta tudo na oficina e me liga, se o mestre não estiver lá, eu desço e ajudo você a trazer até aqui. E o morador deu a ele o seu telefone. Lá estava o morador esperando, esperando, e o ajudante não ligava. Ah, vai se foder. O morador outra vez se vestiu e foi até lá à oficina. $\mathrm{O}$ ajudante estava sentado, fumando, não tinha nada serrado. O morador diz - o que aconteceu? E o ajudante responde não aconteceu nada: é que primeiro a encarregada-técnica tem que vir e ver o quanto que pode gastar de ripa pros consertos. - Pois não preciso de consertos, preciso que façam o assoalho inteiro. - Não sei de nada, amanhã o mestre vem e decide o quanto de ripa precisa, como fazer os consertinhos, ou se é o assoalho todo, mas eu não sei de nada. - Mas ela viu tudo um mês atrás. - Não sei, não sei de nada, vá falar com ela. O morador vai outra vez até a encarregada-técnica, esta diz bem, o que fazer, um é um bêbado, o outro sabe-se lá onde está, o que fazer; amanhã iremos e faremos tudo, faremos os consertos, eu vou acompanhar. No dia seguinte, de fato, vieram e fizeram.

\section{Жимец написах заявмение (Евгений Харитонов)}

Жилец написац заяв ение в ЖЭК, что у него провалился на кухне пол, потрескался Аинолеум, надо поменять. Он вначале обратился к мастерам, те затребовали Авадцать пять рублей за одну работу. Но оказалось, ЖЭК Аелает бесплатно. Секретарша сказала: напишите заяв мение начальнику, наАо вначале чтобы пришла техник-смотритель посмотрела, тогАа станут Аелать. Вы отАайте это заявление технику-смотрителю, а уж даст разрешение начальник. Техник-смотритель при шла через два Аня, сказаАа, Аа, наАо весь пол на кухне поменять. Если только провалы заделать, будет непрочно, вокруг них старая основа посыпется (основа была не из досок, а из прессованных опилок), только у нас минолеума нет. Еще через Аень-два пришел по ее распоря жению мастер, который просиц Авадцать пять рублей за работу, 
посмот рел, сказал не можем делать, у нас минолеума нет. Жилец говорит, Аа вот минолеум, давно межит, я сам купиц. - A, ну тогда разбирайте кухню, мы сейчас с подручным прилем. Жилец разобрал тяжелые вещи. Мастер звонит, не нало разбирать, не придем, теса нет. Жилец звонит женщинесмотрителю - как это они не придут, сказали кухню разо брать, а теперь теса нет. Она помялась по телефону - подождите... ммм... нет теса. - А когда будет? - На днях подвезут, мы вам позвоним; но до конца недели сделаем. Проходит несколько дней, он сам звонит - когда будет тес? Она говорит, а вы позванивайте нам. То он звонит, говорят через день-два будет. Тес, говорят, есть на складе, машины нет его везти. Вот, наконец, он заходит пожаловаться на техника-смотрителя, говорят как раз только привезли тес, завтра начнем вам делать. Назавтра тот мастер приходит, говорит, разбирайте кухню, сейчас приду начнем делать, и помериц ему новый Аинолеум как его резать. Проходит час, нет мастера. Жилец звонит, мастера подзывают к телефону: а мы завтра начнем, а то газ вам будем отключать, придет ся вам два дня без газа. - Какая разница, сегодня вы газ отключите и начнете делать или завтра то же самое; вы же сказали, сейчас придете, я жду вас, кухню разобрац. - Ну, Аадно, тогда придем сейчас. Проходит час с Аишним, жилец одевается и идет в мастерскую на улице. Там того мастера нет, сидит подручный нетрезвый. Подручный говорит, придем завтра. Жилец говорит Аа мне мастер только что сказал по телефону сейчас придет; где мастер? - А он ушел по заявке; обедать ушел: он мне сказал, звонил вам, у вас никого дома не было. - Я же с ним разговаривац, вместе померяли минолеум, он сказал сейчас при Ает с тесом, и три часа его нет, куда он пошел по заявке, в какой Аом? я пойду его найду. Подручный говорит - запишите, и протягивает фанеру. - Ну говорите, говорите, я запомню. А подручный протянул фанеру чтобы жилец написац свой адрес. - Аа зачем мой адрес, мастер же бы у у меня. - Ну как хотите. - Вы мне скажите куда он поше п по заявке, в какой Аом, я пойду его найду. Подручный тут назвац такой адрес, в нем перепутаны цифры из аАреса жильца. Жилец пошел к технику-смотрителю жаловаться на мастеров. Та с ним назад пришла в мастерскую, стала ругать подручного, мастера так и нет, тот гово рит - мастер с утра ходиц вот в квартиру этого жильца, которому на кухне пол перестилать, сказал его дома нет, завтра пойдем. Жилец уже не возразия, видит бесполезно. Техник-смотритель велела подруч ному пока начинать работу, напилить полосы теса по размерам кухни, и выгнала заодно из мастерской Аюдей, про которых правильно подо зревала, что они пришли к подручному выпить с ним, и ушла. Подруч ный говорит - а как я буду резать, я размеров вашей кухни не знаю. А все кухни одинаковые во 
всем районе. Жилец говорит - ну хорошо, пойдемте со мной, померяете. Вот пришли они с подручным к жильцу в Аом, подручный измерил кое-как, Аинейка илет вкривь и вкось и говорит - все равно раньше чем через три Аня

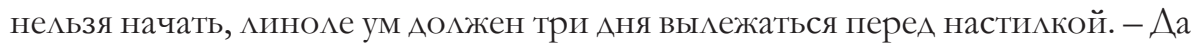
он уже тридцать три Аня вылеживается у меня в комнате! Теперь подручный сказац - а, так у вас свой минолеум, тогда Аругое Аело, можно завтра начать; так зачем я мерил по кухне как его резать, какого размера полосы теса делать,

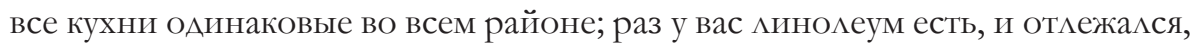
так завтра можно начать. - Аа как так завтра, мне мастер пришец сказал сегодня; начинайте сегодня; если не успеете, завтра продолжите; пойдите хоть напилите полосы теса по размерам и принесите сюда. Подручный сказал все равно без мастера не смогу. - Что не сможете? Отпилить не сможете? Отпилить могу, а как понесу, полосы большие, у меня сиц нет нести. - Ну хорошо, вы илите отпилите в мастерской и позвоните мне, если еще ваш мастер не прише , я спущусь к вам помогу Аонести. И жилец записал ему телефон. Вот жилец сидит жАет, жАет, не звонит подручный. О, еб твою мать. Жилец опять оделся пошел к нему в мастерскую. Подручный сидит курит, ничего не напилено. Жилец говорит - в чем дело? А под ручный как ни в чем не бывало: а сперва к вам должна прийти техник- смотрите ь посмотреть сколько садить из теса заплаты. - Аа мне не заплаты, мне весь пол делать надо. - Ничего не знаю, завтра техник при дет и решит сколько теса на вас, какую делать заплатку, или на весь пол, а я ничего не знаю, идите к ней. Жилец опять к технику-смотрителю, та сказала, ну что Аелать, этот пьяный, тот неизвестно где, что Аелать; завтра придем и все слелаем, сделаем заплаты, я прослежу. Назавтра, правда, пришли слелали.

\section{TRAIÇÃO-80 (Evguêni Kharitónov)}

\section{Antiutopia}

Pois então, a Praça Vermelha estava tomada de gente. E o povo avançava, avançava e avançava. "Abaixo o canalha comunista!" - gritavam. Todos usando losangos anticomunistas. Assim havia sido ordenado. Escavaram um buraco onde ficava o mausoléu. O morto em pessoa jazia logo ali. Todos esperavam seu fim solene. Afinal, aproximou-se um rolo compressor, desses que recapeiam o asfalto, e amassou o morto como uma panqueca. Mas, antes disso, tinham sorteado algumas pessoas, dado a elas pílulas vomitórias para que elas vomitassem no rolo do rolo compressor. Pois foi justamente com esse rolo lambuzado que passa- 
ram por cima do cadáver, sob a marcha de Beethoven, tocada num sintetizador. Davam melancias e cerveja aos soldados defronte ao buraco, e eles urinavam lá dentro. E depois disso emergiram a panqueca ali. Foi explicado a todos, é claro, que estavam afogando um cadáver com 60 anos de jazigo; o jovem Uliánov $^{3}$, porém, era coisa bem diferente, ele tinha intenções genuínas e era digno de estar nos museus. Ele, sem dúvida, desejava o bem para seu bronco país, mas havia nele muito de tártaro, de Kazan. E em volta também. Foi a contragosto que ele passou agir por meios tártaros. Se bem que, por outros meios, possivelmente, não teria dado em nada. Possivelmente, os liberais Miliukov, Gutchkov, Pobedonóstsev ${ }^{4}$ não poderiam ter feito nada com a Rússia, teriam sido devorados. Pois até Blok, por exemplo, de natureza tão refinada, não os compreendia e desejava ser um esquife 5 . Somente pelos meios tártaros de Lênin foi possível destruir a Rússia, arruinar seu estúpido aparato burocrático - porém! Porém o Evangelho! Terno e penetrante, o único ensinamento cristão confiável sobre a compaixão, o amor, sobre não haver alegria na terra, era preciso deixar isso às crianças na escola e aos adultos nas universidades de cultura. Pois ele foi fechando as igrejas. Com tais ensinamentos, os infortúnios da vida passariam de forma bem mais sóbria do que com as promessas comunistas. E outro "porém", questão prática. Lênin não era espião alemão o suficiente ${ }^{6}$. Como seria possível confiar o governo da Rússia aos russos - e aos judeus, russificados, que adquiriram todos os traços ruins dos russos, somados aos seus próprios, já não muito bons. Assim sendo, seria necessário chamar os Varegues ${ }^{7}$, como no começo da história russa? Não, os Varegues não entenderiam aquele momento e fariam da Rússia uma simples

3 Verdadeiro sobrenome de Lênin (N.T.).

4 Pável Nikoláevitch Miliukov (1859-1943) - um dos organizadores do Partido Constitucional Democrata, redator do jornal Riétch. Em 1917, tornou-se ministro de relações exteriores da primeira formação do Governo Provisório; Aleksandr Ivánovitch Gutchkov (1862-1936) - líder do partido "União do 17

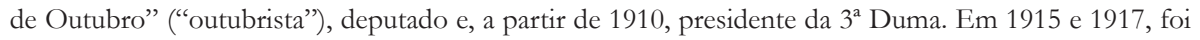
presidente do Comitê Bélico-Industrial, e, em 1917, ministro de guerra durante o Governo Provisório; e Konstantin Petróvitch Pobedonóstsev (1827-1907) - Procurador Geral do Santíssimo Sínodo, de 1880 a 1905. Sua filiação aos "liberais" não se aplica. (N.E.)

5 Tem-se em vista o poema de Aleksandr Aleksándrovitch Blok (1880-1921) “Esquifes” (“Скифы”), de 1918 (N.E.).

6 Em julho de 1917 começou a circular o boato de que Lênin, bem como outros líderes bolcheviques, eram espiões a serviço da Alemanha. Entre as principais provas a este respeito estavam documentos publicados pelo Governo Provisório, segundo os quais o Partido Bolchevique teria recebido subsídio financeiro do governo alemão nos anos de 1916 e 1917. (N.E.)

7 Povo viking que, entre os séculos XI e XII, navegou da Escandinávia em direção ao Leste europeu, fixando-se nos territórios que dariam origem à Bielorrússia, Rússia e Ucrânia. (N.T.) 
colônia. Eles mesmos ainda não teriam aprendido a respeito da experiência do socialismo. Eles devolveriam a Rússia ao seu tsar, à corte, e tudo voltaria àquela mesmíssima revolução e à expulsão deles, os forasteiros. E chegaria, por fim, o momento de chamar Riúrik ${ }^{8}$. Europeus qualificados e gestores americanos, atualmente, se convidam para ocupar todos os grandes (e pequenos) postos, mediante acordo. Seriam todos convidados de diferentes países, sem nenhum tipo de preponderância. O trabalho criativo - científico, artístico - continuaria sendo nosso. Mas já que de nós não sai administração alguma, nós então chamamos vocês para ajudar, caros senhores, sejam bem-vindos!

A fronteira do país, a leste, se desloca até o Enissiéi ${ }^{9}$ Krasnoiarsk ${ }^{10}$ é o ponto fronteiriço. (É possível que o renomeiem para Tchaadáev ${ }^{11}$.) Toda a população, incluindo aí Vladivostok ${ }^{12}$ e Sakhalina ${ }^{13}$, se transfere para cidades novas, especialmente construídas, na Sibéria Ocidental. O território liberado será doado à China. Deixem que os chineses façam o que quiserem com ele. Porém para cá, depois de Tchaadaevo ${ }^{14}$, não os deixaremos passar. Esperemos, pois, que eles se contentem com território desses. Bom, eles são muitos mesmo, precisam viver em algum lugar e comer alguma coisa.

As repúblicas da União.

Aos Países Bálticos, como à Europa, será permitido sair da composição desse novo estado. Aliás, é decisão deles. Possivelmente, diante de um novo direcionamento, não vejam sentido em sair.

O Cáucaso permanece conosco de qualquer jeito, pois é desatinado e belicoso. Além disso, há petróleo em Baku.

Os nômades (Cazaquistão). Os nômades continuam como antes sendo colônia, porque ainda não amadureceram tudo que tinham para amadurecer.

8 Rurik de Kíev (830-879) - chefe dos varegues que, de acordo com as crônicas antigas, foi chamado no ano de 882 d.C. para tornar-se príncipe da Rus. Governou as regiões de Ladoga e Nóvgorod, ao norte da Rússia. (N.E.).

9 Rio siberiano que desemboca no Oceano Ártico. É tido como a linha divisória entre o Oriente Médio e o Extremo Oriente. (N.T.)

10 Capital do território de Krasnoiarsk, na Sibéria Oriental. A cidade é cortada pelo rio Enissiéi. (N.T.)

11 Piotr Iákovlevitch Tchaadáev (1794-1856) - filósofo russo, autor de uma série de cartas filosóficas em que criticava o atraso da Rússia (N.T.)

12 A maior cidade portuária da Rússia no Oceano Pacífico e uma das maiores da Sibéria. É a parada final da Transiberiana. (N.T.)

13 Ilha russa localizada no Mar do Norte, atualmente habitada por povos autóctones e russos. Entre a década de 1860 até meados de 1900 foi usada pela Rússia como ilha de desterro. (N.T.)

14 Povoado da região de Vladímir, nas proximidades de Moscou. (N.T.) 
A questão com as repúblicas instruídas da União (tajiques, uzbeques) se resolve como a dos Países Bálticos. A Pequena Rússia (Ucrânia), a Rússia Branca (República Bielorrussa Piotr Macherov ${ }^{15}$ ) - elas é que decidem. Caso a Ucrânia saia, então a Crimeia sai com ela e torna-se um território neutro, como a Suíça.

O censo para os representantes judeus na administração permanece limitado, como antes, - para evitar uma abrupta explosão de antissemitismo, no caso de alguma falta de sorte no governo.

Bem, como as questões domésticas não são da nossa alçada, passemos de uma vez para as questões de ideologia, moral e diversão.

Pois bem, com o mausoléu já terminamos. O que vamos fazer com o Kremlin? É claro, a tentação de fazê-lo voar pelos ares e queimá-lo é grande. E eternizar este momento em transmissões ao redor do mundo todo. Seria muito importante não se ater a certas relíquias, como se elas estivessem aderidas ao coração da Rússia. De toda forma, elas carregam consigo um significado bizantino. A qualquer momento, um monumento como esse pode se tornar o lar de antigos estados de espírito. Além disso, queimar uma relíquia seria, outra vez, exagero russo. Eis o que nos propõem os camaradas ocidentais, e nós, com prazer, obedecemos. Abrir no Kremlin a melhor Casa de Encontros paga, para que ela seja o ornamento de todo o nosso território. E aí precisaríamos das moças de nossas colônias - Ásia Central, Norte. Cossacas, iacutas ${ }^{16}$, nanaiquinhas ${ }^{17} \mathrm{e}$ representantes do outro sexo. A Casa Pública "Kremlin” será ornamentada com uma iluminação noturna (mas não brilhante, ofuscante), que ficará tremeluzindo e piscando, como luzinhas na igreja ou num pinheirinho de Natal.

Na ideologia, vão incentivar e até mesmo impor (as instâncias responsáveis se encarregarão disso) os impropérios e as maldições direcionadas à nova vida e ao poder. Quanto mais a xingarem abertamente, tanto menos restará algo por dizer. A ideologia da difamação se tornará predominante. Entretanto, para proteger aqueles que são xingados dos atos grosseiros dos xingadores e para que os impropérios se mantenham apenas no âmbito das palavras, em formas figuradas, será criada uma rede especial de serviços. Vocês, é claro, entendem que o quadro

15 Piotr Mirónovitch Machérov (1918-1980) foi o primeiro secretário do Partido Comunista da Bielorrússia, a partir de 1956. Gozava de grande autoridade na Bielorrússia e estava cotado para ser o presidente do Soviete dos Ministros da URSS. Morreu em 04 de outubro de 1980, num acidente de carro, sob circunstâncias suspeitas, levando à suposição de assassinato. (N.E.)

16 Povo turcomano que habita, especialmente, a República da Iacútia (norte da Sibéria). (N.T.)

17 Em russo, “нанаечки”, diminutivo de “нанайцы”, isto é, o povo nanái, de origem tungue, que habita as margens do rio Amur e afluentes, na Rússia e na China. Também conhecidos como "hezhen”. (N.T.) 
desse sistema será composto por ex-funcionários dos órgãos de segurança do Estado e pelos recém-formados nessa escola. De modo geral, essa organização será apreciada por nós como sendo única e perfeita dentre todas as existentes, dentre todas as obras socialistas em todos os anos de organizações econômicas, culturais e científicas. Justamente ela irá observar a afabilidade europeia junto aos funcionários da esfera de serviços - novamente estimulando conversas funestas direcionadas à nova revolução, aos governantes, proferidas nas filas que, é claro, nos primeiros dez dias, e até mesmo durante a administração europeia, ainda não terão desaparecido. Porque como é difícil ficar de pé numa fila, como é difícil ver o desaparecimento de vários produtos, mas é ainda mais difícil não poder, amaldiçoando o canalha comunista, juntar um monte de catarro na boca e cuspir com gosto em seus retratos. "Pode, - diz aquilo agora o que antes fora o KGB. - E é até mesmo preciso". E ele próprio realizará esse gesto artístico. Ao mesmo tempo, ele protege, e com justiça, as autoridades de atentados a suas vidas. Pois, de fato, não é nada fácil administrar um país assim imenso. Aliás, que se tornou menor agora.

Uma das inovações interessantes dessa ideologia será a permissão da linguagem de baixo calão. Haverá o incentivo de espetáculos de televisão, filmes no cinema etc. que mostrem tudo que todo inimigo, por puro ódio, está pronto a imaginar, e até mesmo com cores ainda mais concentradas, sinistras, sacrílegas. Ao mesmo tempo, para balancear, e respeitando os costumes e o bom-gosto, protegendo a saúde da geração mais velha, continuarão a criar produções leves, atenuadas (um ou dois canais de televisão, o mesmo no rádio). E vai ser mesmo agradável para as pessoas da geração intermediária, e da nova também, assistir a programas assim. Eles parecerão originais em oposição àqueles pérfidos e serão comoventes.

O palavreado baixo será expresso em letras luminosas (também com luzinhas tremeluzentes) nas casas. Ao mesmo tempo, àqueles que queiram ver nisso os sinais do apocalipse, concederão um megafone para que expressem abertamente esse pensamento. Só não será permitido deixar de dizer alguma coisa, esconder alguma coisa sobre si. Aquilo sobre o que não quiserem falar será considerado socialmente perigoso. Por isso os antigos órgãos de segurança do Estado ficarão observando, para que de forma alguma reste algo por dizer. Ao mesmo tempo, àqueles que desejarem calar e esconder-se, também concederão esse direito e haverá até clubes de silêncio.

A questão da igreja resolve-se assim: não haverá nenhum renascimento. Lá e cá, especialmente nas novas cidades industriais, abrir-se-ão umas igrejinhas; nos novos bairros das grandes cidades também; mas de modo muito limitado. Levando em conta a maleabilidade especial dos nossos habitantes a todo tipo de influência 
autoritária, ainda mais a influências de uma instituição dessas, autoritária e poderosa, como a nossa igreja; levando em conta como a igreja paralisa, no nosso caso, manifestações livres e vitais - não se deve permitir a sua expansão. Repetimos, isso não se relaciona de modo algum aos ensinamentos do evangelho em si, que devem ser, de todas as formas, saudados, lembrados nos manuais escolares, nos programas infantis - nos de televisão, nas reuniões de pioneiros, nos espetáculos de cultura de massa. Além disso, na igreja ortodoxa atual não se permite nenhum tipo de reforma. Nem a menor das inovações. Ela deve permanecer tal e qual sempre foi. Para que, se vocês quiserem entrar numa delas, entrem justamente numa igreja ortodoxa russa, e não numa sabe-se lá qual.

Pois então, resumindo. A experiência de Pedro II (Uliánov-Lênin) no que diz respeito ao desmoronamento da Rússia considera-se bem-sucedida, um sucesso. Entretanto, a manobra não foi levada a cabo. Para que houvesse o remate final, teria sido necessário recrutar forasteiros para o governo, como no começo da história russa. Visando a prevenção de descontentamento nacional, fez-se necessário desenrolar uma rede de clubes de totalitarismo artificial, organizar festividades em estádios com a performance de canções dos tempos estalinistas etc.

Desta forma, todos os propósitos foram mais ou menos alcançados. Mas se vocês, de toda forma, amam a saudade e a tristeza, então resta uma última, uma verdadeira saudade, que muitos não conheciam, por conta de pequenos infortúnios. Quando tudo é possível, ela mesmo assim se torna maior e maior. Só que esta não será uma saudade de alguma filazinha por aí, mas sim uma saudade verdadeira, mortal.

Pois então, bem-vindos, senhores, à nossa terra.

\section{ПРЕААТЕАЬСТВО-80 (Е. Харитонов)}

\section{Антиутопия}

Итак, Красная площадь была запружена народом. Он шел, шел и шел. «Долой коммунистическую сволочь!» - кричал он. Все несли антисоветские цозунги. Так всем было приказано. На месте мавзолея выкопали яму. Сам мертвец межал невдалеке. Все ожиАали его торжественной казни. Наконец подъехац каток, которым раскатывают асфальт, и раскатац мертвеца в цепешку. А переА этим выбрали по Аотерее несколько человек, им Аали рвотного порошка, чтобы их стошнило на вац катка. Вот этим-то измазанным ва^ом и проехали по трупу под марш Бетховена, сыгранный на 
синтезаторе. Соцдатам возце ямы дали арбузов и пива, и они помочились в яму. А уж затем мепешка была потоплена в ней. Конечно, всем было объяснено, что это топят труп 60-ти мет межания; а сам-то по себе юноша

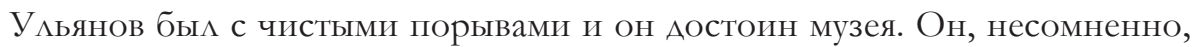
хотел хорошего своей грубой стране, но слишком много в нем самом было татарского, казанского. Аа и вокруг. И он поневоле стац Аействовать татарскими методами. Впрочем, Аругими, возможно, ничего бы не вышло. Возможно, миберальные деятели, Милюков, ГАучков, Победоносцев ${ }^{18}$, ничего бы не смогли слелать с Россией, их съели бы. Ведь Ааже Блок, например, такая тонкая натура, не воспринимал их и хотел быть скифом ${ }^{19}$. Только татарскими методами Аенина можно было разрушить Россию, поломать ее тупой бюрократический аппарат, - но! Но Евангелие! нежное и проникновенное, единственно верное христианское учение о сочувствии, о Аюбви, о том, что нет на свете счастья, надо было оставить детям в школе и взрослым в университетах культуры. Раз он позакрывал церкви. С этим учением гораздо трезвее переносятся жизненные невзгоды, чем с коммунистическими обещаниями. И Аругое «но», совсем практическое. Аенин был недостаточно немецким шпионом ${ }^{20}$. Как можно было доверить править Россией русским - и евреям, обрусевшим, перенявшим все плохие русские черты плюс к неважным своим. Так что же, нало было позвать Варягов, как в начале русской истории? Нет, Варяги не поняли бы того момента и слелали бы хз России простую колонию. Они тогАа еще сами не научены были опытом социализма. Они вернули бы России ее царя, Авор, все снова пришло бы к той же революции и х их, иноземцев, изгнанию. И вот, наконец, время приглашения Рюриков ${ }^{21}$ настало. Квалифицированные европейские и американские управляющие приглашаются сегодня занять

18 Упоминуты: Милюков Павел Николаевич (1859-1943) - один из организаторов партии кадетов, редактор газеты «Речь». В 1917 году - министр иностранных дел Временного правительства 1-го состава. Гучков Александр Иванович (1862-1936) - лилер партии «Союз 17 октября» («октябристов»), депетат и с 1910 года председатель 3-й Государственной думы. В 1915-1917 годах - председатель Центрального военно-промышленного комитета. В 1917 году военный и морской министр Временного правительства. Победоносцев Константин Петрович (1827-1907) - 1880-1905 годах оберпродуктор Святейшего Синода. Причисление последнего к «либеральным деятелям» неспраАливо. 19 Имеется в виду поэма Александра Александровича Блока (1880-1921) «Скифы» (1918).

20 Имеется в виАу возникшая в иб̆ле 1918 года версия о шпионской деятельности Аенина и Аругих Аидеров большевиков в пользу Германии: одним из доказательств обвинения служили опубликованные Временным правительством документы, согласно которым партия большевиков получала в 1916-1917 годах денежные суб̆сидии от германского правительства.

21 Рюрик - согласно метописям, глава военного отряда варягов, привазнный в 862 году на княжение на Руси. Правим в Аадоге и в Новгороде. 
все крупные (и мелкие) посты, на договорах. Приглашаются все из разных стран, без преимущества какой-нибудь одной. Творчество - научное, художественное - остается нам. А уж управ ение у нас не выходит, и мы зовем на помощь вас, уважаемые господа, мицости просим!

Граница страны на востоке сдвигается до Енисея. Красноярск пограничный пункт. (Возможно его переименование в ЧааАаев.) Все население, по ВАадивосток включительно и Сахалин, переселяется в новые, специально построенные города Западной Сибири. Освободившаяся территория отдается Китаю. Пусть китайцы делают с ней что хотят. А уж сюда, за ЧааАаево, мы их не пустим. Аа они, надеемся, удовлетворятся и такой территорией. Ведь, правда же, их много, им надо где-то жить и что-то есть.

Союзные республики.

Прибалтике, как Европе, разрешается выйти из состава нового государства. Впрочем, на ее усмотрение. Возможно, при новом управ ении ей и не имеет смысла никуда выходить.

Кавказ остается нам в Аюбом случае, потому что он несознательный и воинственный. Кроме того, в Баку нефть.

Кочевники (Казахстан). Кочевники по-прежнему остаются колонией, потому что до большего пока не доросли.

С просвещенными союзными республиками (таАжики, узбеки) вопрос решается, как и с Прибалтикой. Малая Россия (Украина), Белая Россия (Белорусская республика имени Петра Машерова ${ }^{22}$ ) - вопрос на их усмотрение. В случае отхода Украины от нас Крым изымается у нее и

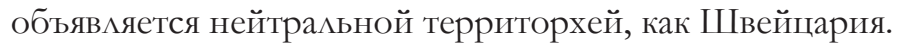

Ценз на иудейских представителей в управцении остается ограниченным, как и прежле, - во избежание резких вспышек юдофобии в случае незадач в правлении.

Так как хозяйственные вопросы дело не нашего ума, переходим сразу к вопросам идеологии, морали и разв ечений.

22 Пётр Миронович Машеров (1918-1980) - советский партнийный и государственный деятель, Герой Советского Союза (1944), Герой Социалистического Труда (1978), член ЦК КПСС (с 1964 года), кандидат в члены Политоююро ЦК КПСС (с 1966 года). С 1965 - 1-й секратарь ЦК компартии Белоруссии. Пользоваашийся большим авторитетом в Белоруссии и рассчитывавший занять пост Председателя Совета минимтров СССР Машеров погиб 04 октября 1980 года в автомобильной катастрофе при обстоятельствах, позволяющих предполагать его умышленное убийство. 
Итак, с мавзолеем покончено. Что будем делать с Кремлем? Конечно, большой соблазн взорвать его и сжечь. И увековечить этот момент в передачах по всему миру. Казалось бы очень важно не держаться за некоторые святыни, как бы они ни приросли к сердцу России. Все равно они несут с собой этот византийский смысл. В юбой момент такой памятник может стать очагом прежних настроений. Впрочем, сжигать святыню опять будет российская крайность. Вот что нам предлагают запаАные товарищи, и мы с удовольствием их послушаем. В Кремле открыть мучший, чтобы он был украшением всей нашей территории, платный Аом свиданий. Вот зАесь и пригодятся девушки наших колоний - Средней Азии, Севера. Казашки, якутки, нанаечки и мица Аругого пола. Публичный Аом «Кремль» будет украшен еженощно им^юминацией (но не яркой, ослепительной), чтобы мерцала и бегала, как огоньки в церкви или на елке.

В идеологии будет поощряться и Ааже вменяться (за этим прослеАят соответствующие инстанции) ругань и проклятие в аАрес новой жизни и властей. Чем больше будут ее открыто ругать, тем меньше будет оставаться невысказанности. ИАеология поношения объяв яяется господствующей. ОАнако чтобы оградить тех, кого ругают, от грубых действий ругающих и чтобы ругань поддерживалась в словах, в изобразительных знаках, - будет создана специальная сеть служб. Вы, конечно, понимаете, что ее кадрами будут бывшие работники органов государственной безопасности и новые выпускники ее школ. Вообще: эта организация оценивается нами как единственная совершенная в своем роде из всех существующих за годы социалистического строительства хозяйственных, культурных, научных организаций. Именно она будет следить за соблюдением европейской Аюбезности у работников сферы обслуживания, - опять же поощряя мрачные речи в аАрес новой революции, в аАрес правителей, произносимые в очередях, которые, конечно, в первые Аесять Аней, Ааже при запаАной аАминистрации, еще не исчезнут. Потому что как ни тяжело стоять в очередях, как ни тяжело видеть исчезновение многих продуктов, но еще тяжелее, что нельзя, открыто проклиная коммунистическую сволочь, смачно, набрав в рот соплей, плевать на их портреты. «Можно, - говорит теперь то, что раньше было КТБ. - И Ааже нужно». И само слелает этот артистический жест. В то же время справедливо охраняя вцасти от покушений на их жизнь. Ведь действительно очень нелегко править такой огромной страной. Впрочем, она же теперь стала меньше.

ОАно из интересных нововведений идеологии - Аозволение мата. Поощрение телеспектаклей, кинофильмов и т. А., изображающих все, 
что каждый ненавистник готов от ненависти измыслить, Ааже в еще более сгущенных, зАовещих, кощунственных красках. В то же время Аця баланса и уважая привычки и вкус, оберегая здоровье старшего поколения, продолжают создаваться мягкие, сглаживающие всё произведения (один или два канала телевидения, то же на раАио). Аа и Аля Аюдей среднего и молодого поколения приятно будет смотреть такие передачи. Они оригинально будут выглядеть на фоне черных и трогать.

Матерщина выкладывается светящимися буквами (тоже перебегающими огоньками) на домах. В то же время тем, кто захочет усмотреть в ней знаки апокалипсиса, предостав яются рупора открыто высказывать и эту мысль. Не разрешается только что-то неАоговаривать, что-то таить про себя. Социально опасным будет считаться то, о чем не хотят говорить. Поэтому бывшие органы государственной безопасности следят, чтобы ни в коем случае ничто не осталось невысказанным. В то же время желающим молчать и таиться тоже предоставляются такое право и такие клубы молчания.

Вопрос с церковью решается так: никакого возрождения. Кое-где, особенно в новых промышленных городках, открывается по церковке; в новых районах больших городов тоже; но очень ограниченно. Учитывая особую податливость нашего населения всяким авторитарным возАействиям, тем более воздействию такого мощного авторитарного учрежления, как наша церковь; учитывая, как парализует церковь, в нашем случае, свободные витальные проявления, - не допускать ее расширения. Повторяем, это никак не относится к самому евангельскому учению, которое Аолжно всячески приветствоваться, напоминаться в школьных учебниках, в детских радио- и телепередачах, на сборах пионеров, в зрелищах массовой

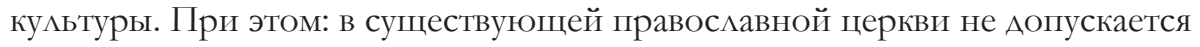
никаких реформации. Ни малейших нововведений. Она должна оставаться такой, какой была. Чтобы, если вы захотели пойти в нее, вы пошли бы в русскую православную церковь, а не в какую-то неизвестно какую.

Итак, резюме. Опыт Петра 2-го (У ььнова-Аенина) в части развала России считать успешным, удавшимся. ОАнако Аиверсия не была им проведена до конца. В делах ее довершения привлечь к управ ению иноземцев, как в начале русской истории. В целях предотвращения национального недовольства развернуть сеть киубов по художественному тоталитаризму, устраивать празднества на стадионах с исполнением песен сталинского времени и т. А. 
Таким образом, все склонности будут более или менее удовлетворены. А уж если вы все равно Аюбите тоску и грусть, так остается настоящая, последняя тоска, которую многие не знали за мелкими невзгодами. КогАа все можно, а она все равно и еще больше. Но это будет не тоска от каких-то там очередей, а настоящая смертельная тоска.

Так что, милости просим, господа, на нашу землю.

\section{Referências}

KHARITÓNOV, E. Jilets napisal zaiavlenie [Um morador escreveu um requerimento]. In: . Pod domachnim arestom [Em prisão domiciliar]. $2^{\circ}$ edição. Moscou: Glagol, 2005, pp. 116-118.

. Jilets napisal zaiavlenie [Um morador escreveu um requerimento]. In: BERMAN, F. et al. Katalog [Catálogo]. Ann Arbor: Ardis, 1982, p. 256-258. Disponível em: http:// vtoraya-literatura.com/pdf/katalog ardis 1982 text.pdf Consulta realizada em 20 de agosto de 2017.

PREDATELSTVO-80 - Antiutopia [Traição-80 - Antiutopia]. In: . Pod domachnim arestom [Em prisão domiciliar]. $2^{\circ}$ edição. Moscou: Glagol, 2005, pp. 399-403. . PREDATELSTVO-80 - Antiutopia [Traição-80 - Antiutopia]. Disponível em: https://openuni.io/course/5-course-4/lesson/2/material/464/ Consulta realizada em 20 de agosto de 2017. 